\title{
The effect of additional viral infections on garlic plants initially infected with Allexiviruses
}

\author{
M. Cecilia Perotto • Eva E. Cafrune • \\ Vilma C. Conci
}

Received: 29 December 2008 / Accepted: 26 October 2009 /Published online: 19 November 2009

(C) KNPV 2009

\begin{abstract}
Yield losses caused by a second viral infection of garlic plants previously infected with either of the isolated Allexiviruses, Garlic virus-A (GarV-A) or Garlic virus-C (GarV-C), were evaluated in a field assay carried out over four consecutive growing seasons. The treatment groups included virus-free plants (VF), plants infected only with GarV-A isolates (A), plants infected only with GarV-C isolates (C), and plants infected with a mixture of viruses that naturally infect garlic, referred to as viral-complex plants (VC). From the first crop cycle the different treatments were infected by other viruses that naturally infect garlic. At the end of the first growth cycle, significant differences in yield were observed among the four treatments. The bulb weight for $\mathrm{VF}, \mathrm{C}$, and A treatments was respectively $137 \%, 116 \%$, and $96 \%$ higher than the bulb weight for the VC treatment. After the fourth growth cycle, however, non-significant differences in garlic yield between the VC, C, and A treatments were observed,
\end{abstract}

M. C. Perotto - E. E. Cafrune - V. C. Conci

Institute of Phytopathology and Vegetal Physiology-

National Institute of Agricultural Technology (IFFIVE-

INTA),

Camino 60 Cuadras Km 5 1⁄2 (5119),

Córdoba, Argentina

V. C. Conci $(\bowtie)$

National Council of Scientific and Technical Researches (CONICET),

Córdoba, Argentina

e-mail: vconci@correo.inta.gov.ar whereas the yield for the VF treatment was higher than the VC treatment by $22 \%$. Garlic yield decreased more rapidly in plants infected previously with at least one Allexivirus and then infected with other naturally occurring viruses than the plants that were virus-free at the beginning (VF plants).

Keywords Allium sativum L. Garlic virus-A . Garlic virus-C.

\section{Introduction}

In plants with exclusive vegetative propagation, such as garlic (Allium sativum L.), viral diseases are a key factor in influencing crop yields. The viruses can accumulate in the bulbs and perpetuate the viral infection from one generation to the next. Garlic mosaic is a viral disease that is widespread throughout all cultivation areas. The disease is caused by a complex of viruses belonging to the genera Potyvirus, Carlavirus (aphid-borne viruses), and Allexivirus (mite-borne viruses), and can cause significant losses in crop yield. In addition, the bulb weight of virusfree garlic plants has been shown to be 32-216\% higher than infected plants for most cultivars tested (Conci 1997; Conci et al. 2003; Melo Filho et al. 2006; Walkey and Antill 1989).

The Carlaviruses, Garlic common latent virus (GCLV) and Shallot latent virus (SLV), have infected garlic crops in various countries (Barg et al. 1994; 
Nieto et al. 2004; Tsuneyoshi et al. 1998; Van Dijk 1993) but until now, the effect on crop yields for garlic has not been determined.

Traditionally, the greatest economic losses from crop yields were attributed to the presence of the Potyvirus, Onion yellow dwarf virus (OYDV), and to a lesser extent Leek yellow stripe virus (LYSV). In the presence of these viruses, bulb weight was found to be reduced by $69 \%$ due to OYDV, and by $54 \%$ due to LYSV (Canavelli et al. 1998; Lot et al. 1998; Lunello et al. 2007).

In Argentina, an Allexivirus was detected that shared $90 \%$ nucleotide sequence homology with the capsid protein of Garlic virus-A (GarV-A, Helguera et al. 1997a). Subsequently, Garlic virus-C (GarV-C) and Garlic virus-D (GarV-D) were detected in garlic samples collected from different areas of Argentina (Cafrune and Conci 2002; Quiroga et al. 2005). These and other Allexiviruses have been detected in various garlic-producing areas of the world, demonstrating the widespread presence of these viruses (Barg et al. 1994; Chen et al. 2004; Tsuneyoshi and Sumi 1996; Van Dijk et al. 1991).

Damage produced by two Allexiviruses, identified as GarV-A and GarV-C, were studied in Argentina. GarV-A caused a significant reduction in bulb weight (14\% to $32 \%$ ) compared with virus-free garlic plants in two cultivars, Blanco IFFIVE and Morado INTA. GarV-C only reduced bulb weight by $15 \%$ compared to virus-free plants in garlic cv. Blanco-IFFIVE, and did not produce significant yield losses in cv. Morado-INTA (Cafrune et al. 2006).

To control garlic viruses, virus-free plants are obtained from meristem culture. This process for commercial production takes some time, and it can include complications due to low rates of multiplication for garlic plantlets $(1: 10 ; 1: 20)$. It is also difficult to eliminate all of the viruses that infect garlic. Furthermore, the determination of whether the plants are free of viruses is challenging due to many factors. For example, there are at least eight viruses that can infect garlic, specific antiserum is not available for all of the viral strains, and the virus concentration in vivo of garlic plants is low, requiring that any assays of viral infection be highly sensitive. For commercial production of cloves, a long period of hardening and various crop cycles of multiplication in the soil are necessary. It is important that the multiplication of material be carried out in isolated areas where re- infection of the propagated plant can be avoided (Bhojwani et al. 1982; Conci and Nome 1991; Conci et al. 2004). Successful virus eradication also depends on the type of virus involved. For instance, Potyviruses are easily removed, whereas Allexivirus eradication is difficult (Conci et al. 2004; Luciani et al. 1998; Perotto et al. 2003).

After several growth cycles, VF plants still performed better than chronically infected plants despite virus re-infection (Conci et al. 2003; Melo Filho et al. 2006; Van Dijk 1993). The performance in successive growth cycles of plants that have a reduced viral load, yet still contain viruses that are difficult to eliminate, such as the Allexiviruses, has yet to be elucidated. Therefore, the objective of this work was to evaluate yield losses for garlic plants initially infected with the isolated Allexiviruses, GarV-A and GarV-C. Bulb yields were monitored in field assays over four consecutive growing seasons.

\section{Materials and methods}

Serological assays and antisera

Serological detection was achieved using a direct double antibody sandwich enzyme-linked immunosorbent assay (DAS-ELISA) (Clark and Adams 1977) modified for garlic according to Conci et al. (2002). Relative Concentration (RC) was calculated from the ratio of the DAS-ELISA absorbance value (measured at $405 \mathrm{~nm}$ ) of the sample and the mean plus twice the standard deviation of the DAS-ELISA absorbance of five healthy control samples tested in the same plate (Conci et al. 2002). Absorbance readings were measured using a Dynatech MR 4,000 spectrophotometer (Dynatech, Guernsey Channel Islands, UK). Isolates and virus-free plants were differentiated from infected plants using immunosorbent electron microscopy plus decoration (ISEM-D) (Milne and Luisoni 1977).

Antisera to OYDV, LYSV, GarV-A, and GarV-C, as well as an antiserum obtained from garlic plants infected with a mixture of naturally occurring viruses (Mix-antiserum) were obtained from the stock of IFFIVE-INTA as described in Cafrune et al. (2005); Conci et al. (1999); Helguera et al. (1997a, b); and Lunello et al. (2002). "Garlic yellow stripe virus" antiserum was kindly provided by M. Carvalho from Federal University of Vicosa (Vicosa, Brazil) and R. 
Shepherd from Univ. of California, Davis (Carvalho 1981; Carvalho et al. 1981). Although this antiserum was obtained from a mixture of viruses, it has been shown to detect Allexiviruses (Conci, unpublished results). SLV antiserum was kindly provided by L. Bos and D. Maat from the Research Institute for Plant Protection (Wageningen, The Netherlands). GarV-C and GarV-A antisera were kindly provided by S. Sumi from the Institute for Biotechnology Research, Wakunaga Pharmaceutical. GCLV and GarV-D antisera were kindly provided by D.E. Lesemann, H.J. Vetten, and E. Barg from the Federal Biological Research Centre for Agriculture and Forestry (Braunschweig, Germany). Antisera against GCLV and SLV were obtained from BIOREBA, and were used according to the manufacturer's directions.

\section{Plant material}

The cultivar used in these studies was Blanco-IFFIVE, a White garlic type, which has a growth cycle of 210 230 days. Virus-free plants (VF) were obtained by meristem-tip culture, as described by Conci and Nome (1991) and Conci et al. (2004), and were analyzed by ISEM-D using the antisera listed. GarV-A and GarV-C isolates were obtained as described by Cafrune et al. (2006) and were maintained through vegetative propagation. Briefly, leaves were macerated in $0.05 \mathrm{M}$ borate buffer ( $\mathrm{pH} 8.1$ ) and mechanically transmitted with 300 mesh Carborundum to Chenopodium murale plants. Tissue from each Allexivirus local lesion was cut and macerated in $0.05 \mathrm{M}$ borate buffer $(\mathrm{pH} 8.1)$ before being used as inoculum to infect new leaves of C. murale. A ratio of one lesion to one leaf was used for infection. This procedure was repeated six times to obtain virus isolates. Recovered isolates were analyzed by ISEM-D with the antisera listed. One isolate each of GarV-C and GarV-A were selected. The purity of the isolates was determined using ISEM-D with antiserum diluted 1:500 and serial dilutions ranging from 1:25 to $1: 6,400$. Each virus isolate was mechanically transmitted to virus-free garlic plants in $0.05 \mathrm{M}$ borate buffer (pH 8.1) with 300 mesh Carborundum. The infected plants from each isolate were maintained and multiplied in individual anti-aphid cages. After 6 months, each infected plant was tested by ISEM-D with the antisera listed to confirm the virus condition. Bulbs produced by infected plants were harvested, disinfected using Micronized Sulphur $80 \%$ DP, and stored in a dry place at room temperature until the start of the next crop cycle. The treatment groups included VF, plants infected only with GarV-A isolates (A), plants infected only with GarV-C isolates (C), and plants infected with a mixture of viruses that naturally infect garlic, referred to as viral-complex plants (VC).

One year before starting an assay, plants from each of the four treatments (VF, VC, C, and A) were multiplied in individual anti-aphid cages $(2 \mathrm{~m} \times 1 \mathrm{~m})$, one per treatment. Cloves were planted at $10 \mathrm{~cm}$ distances within rows that were $30 \mathrm{~cm}$ apart to obtain bulbs subjected to the same environmental conditions. The virus status of each treatment was checked before analysis of samples by DAS-ELISA and ISEM-D.

\section{Field experiments}

Experiments were performed in the research field of IFFIVE-INTA in Córdoba, Argentina. Each year the experimental design consisted of four completely randomized blocks, each block containing five plots, one per treatment. Each plot contained 20 cloves at $15 \mathrm{~cm}$ distances within rows that were $60 \mathrm{~cm}$ apart. The field experiments were conducted for four consecutive years. Cloves were planted in April and harvested in mid-November. Starting with the second crop cycle, bulbs harvested in the previous cycle were used as "seed cloves". This was repeated for the third and fourth crop cycle.

Due to the direct relationship between the size of the planted cloves and bulb size at harvest, cloves of equal size were used for each treatment. Clove size was standardized using two sieves measuring $1.5 \mathrm{~cm}^{2}$ and $1 \mathrm{~cm}^{2}$. Cloves used for planting were those retained by the second sieve (category 2). Before planting in the field, cloves were disinfected by immersion in a suspension of captan (Captan Tomen WP 80\%, $25 \mathrm{~g}$ ), procymidone (Sumilex 50 SC 50\%, $15 \mathrm{~g}$ ), PCNB (pentachloronitrobenzene, WP 78, 2\%, $15 \mathrm{~g}$ ), benomyl (Benlate WP 50\%, $25 \mathrm{~g}$ ), and dimetoate (Dimetoato $40 \%$ Bayer LE, $125 \mathrm{ml}$ ) in 251 of water for $15 \mathrm{~min}$. Soil solarization was applied to the experimental area and the soil surface was covered with plastic $(200 \mu \mathrm{m})$. During the three summer months the average temperature was $23^{\circ} \mathrm{C}$. During the crop cycle the plants were weekly sprayed with tebuconazole (Folicur $25 \mathrm{EW,}$ 0.5 l/ha), mancozeb (Mancozeb 80 HELM, 1.8$2.5 \mathrm{~kg} / \mathrm{ha}$ ), and cipermetrina (Glextrin $25 \mathrm{LE}$, $100 \mathrm{~cm}^{3} /$ ha). Plants were irrigated every 7-10 days. 
After harvest, bulbs were disinfected with Micronized Sulphur $80 \%$ DP, dried, and stored at room temperature (approximately $15-25^{\circ} \mathrm{C}$ ). Thirty days after harvest the bulbs were weighed using a precision balance.

From each year of samples, 25 leaves, one per plant, were randomly selected from each treatment (5 per plot) to evaluate virus infection by DASELISA. An average viral RC was determined for each treatment in each year and was compared with the absorbance values of different viruses.

\section{Statistical analysis}

Treatments were compared by ANOVA and when needed, the Fisher-LSD multiple comparisons test was applied. Analyses were performed using InfoStat (2004) statistical software.

\section{Results}

Differences in yield between the VF and VC plants were observed starting in the first growth cycle, and remained significant over four seasons (Table 1). Significant differences were also observed among the four treatments. Bulb weights of the VF, C, and A were respectively $137 \%, 116 \%$, and $96 \%$ higher than that for the VC plants. In the second year, no significant differences in bulb weight were observed between the
VF and C treatments; however, those bulb weights were significantly higher than the bulb weights of the $\mathrm{A}$ and $\mathrm{VC}$ treatments. In year 3, differences between the bulb weight for $\mathrm{A}$ and $\mathrm{C}$, with respect to $\mathrm{VC}$, were small, and in year 4 they became insignificant. Crop yields of $\mathrm{A}, \mathrm{C}$, and $\mathrm{VC}$ treatments were not significantly different and VF was the only treatment with a significantly higher yield than the VC plants (by 22\%).

All the treatments were infected by viruses from the first year of assay. The VC treatment contained a high percentage of infected plants and $\mathrm{RC}$ values of OYDV, LYSV, and GarV-A which were consistent with the crop yields obtained. In the second year, the VC treatment exhibited the highest percentage of infected plants and of RC values for Potyviruses (OYDV and LYSV). In the subsequent years of the assay, values of virus infection did not follow a clear trend with respect to bulb weight. ANOVA of the RC from different viruses showed significant differences among the treatments in some cases, however, the highest concentrations did not correlate with the lowest yields (Tables 1 and 2).

\section{Discussion}

In virus-free plants, the effects of an infection can be delayed for many growth cycles. For example, after the fourth growth cycle VF plants produce the largest
Table 1 Yield, measured as bulb weight ( $\mathrm{g}$ ), and percentage of increase with respect to virus complex during four crop cycles

\footnotetext{
${ }^{\text {a }}$ Virus-free plants $(V F)$; plants infected only with GarV-A isolates $(A)$; plants infected only with GarV-C isolates $(C)$; and plants infected with a mixture of viruses that naturally infect garlic referred to as viralcomplex plants $(V C)$

${ }^{\mathrm{b}}$ Means followed by different letters are significantly different according to Fisher's test $(p \leq 0.05)$
}

\begin{tabular}{|c|c|c|c|c|c|}
\hline \multirow[b]{2}{*}{1 st year } & \multirow{2}{*}{$\frac{\text { Treatments }^{\mathrm{a}}}{\mathrm{VF}}$} & \multirow{2}{*}{$\frac{n}{85}$} & \multicolumn{2}{|c|}{ Bulb weight $(\mathrm{g})^{\mathrm{b}}$} & \multirow{2}{*}{$\frac{\text { Percentage of increase }}{137}$} \\
\hline & & & 71.57 & $\mathrm{a}$ & \\
\hline & $\mathrm{C}$ & 81 & 65.14 & $\mathrm{~b}$ & 116 \\
\hline & A & 77 & 59.18 & $\mathrm{c}$ & 96 \\
\hline & $\mathrm{VC}$ & 101 & 30.19 & $\mathrm{~d}$ & 0 \\
\hline \multirow[t]{4}{*}{ 2nd year } & VF & 77 & 16.26 & $\mathrm{a}$ & 22 \\
\hline & $\mathrm{C}$ & 80 & 15.90 & $\mathrm{a}$ & 19 \\
\hline & A & 72 & 12.90 & $\mathrm{~b}$ & 0 \\
\hline & $\mathrm{VC}$ & 71 & 13.33 & $\mathrm{~b}$ & 0 \\
\hline \multirow[t]{4}{*}{3 rd year } & VF & 114 & 58.82 & $\mathrm{a}$ & 123 \\
\hline & $\mathrm{C}$ & 94 & 37.48 & $\mathrm{~b}$ & 43 \\
\hline & A & 91 & 33.05 & $\mathrm{~b}$ & 26 \\
\hline & $\mathrm{VC}$ & 94 & 26.30 & $\mathrm{c}$ & 0 \\
\hline \multirow[t]{4}{*}{4 th year } & VF & 70 & 35.91 & $\mathrm{a}$ & 22 \\
\hline & $\mathrm{C}$ & 72 & 30.16 & $\mathrm{~b}$ & 2 \\
\hline & A & 69 & 28.15 & $\mathrm{~b}$ & 0 \\
\hline & $\mathrm{VC}$ & 68 & 29.40 & $\mathrm{~b}$ & 0 \\
\hline
\end{tabular}


Table 2 Viral relative concentration (RC) values and percentage of plants infected for each treatment with each virus in the four growth cycles

${ }^{\text {a }}$ Virus-free plants $(V F)$; plants infected only with GarV-A isolates $(A)$; plants infected only with GarV-C isolates $(C)$; and plants infected with a mixture of viruses that naturally infect garlic referred to as viralcomplex plants $(V C)$

${ }^{\mathrm{b}}$ Mean of viral relative concentration $(R C)$

${ }^{\mathrm{c}}$ Different letters are significantly different according to Fisher's test $(p \leq 0.05)$

${ }^{\mathrm{d}}$ Percentage of virusinfected plants

${ }^{\mathrm{e}}$ Without data

\begin{tabular}{|c|c|c|c|c|c|c|c|c|c|c|c|c|c|}
\hline & \multirow[t]{2}{*}{$\mathrm{T}^{\mathrm{a}}$} & \multicolumn{3}{|c|}{ OYDV } & \multicolumn{3}{|c|}{ LYSV } & \multicolumn{3}{|c|}{ GarV-A } & \multicolumn{3}{|c|}{ GarV-C } \\
\hline & & $\mathrm{RC}^{\mathrm{b}, \mathrm{c}}$ & & $\%^{\mathrm{d}}$ & $\mathrm{RC}$ & & $\%$ & $\mathrm{RC}$ & & $\%$ & $\mathrm{RC}$ & & $\%$ \\
\hline \multirow[t]{4}{*}{ 1st year } & $\mathrm{VF}$ & 1.52 & $\mathrm{a}$ & 64 & 1.73 & $\mathrm{a}$ & 12 & 1.05 & $\mathrm{a}$ & 4 & $\mathrm{wd}^{\mathrm{e}}$ & & \\
\hline & $\mathrm{C}$ & 3.07 & $\mathrm{~b}$ & 88 & 2.28 & $\mathrm{a}$ & 20 & 0 & & 0 & wd & & \\
\hline & $\mathrm{A}$ & 2.55 & $\mathrm{~b}$ & 60 & 2.28 & $\mathrm{a}$ & 8 & 3.99 & $\mathrm{a}$ & 89 & wd & & \\
\hline & $\mathrm{VC}$ & 3.79 & $\mathrm{c}$ & 87 & 1.89 & $\mathrm{a}$ & 53 & 3.26 & $\mathrm{a}$ & 88 & wd & & \\
\hline \multirow[t]{4}{*}{ 2nd year } & VF & 5.36 & $\mathrm{~b}$ & 62 & 5.78 & $a b$ & 4 & 8.01 & $\mathrm{~b}$ & 88 & 4.1 & $\mathrm{a}$ & 96 \\
\hline & $\mathrm{C}$ & 3.18 & $\mathrm{~b}$ & 73 & 1.74 & $\mathrm{~b}$ & 35 & 6.17 & $\mathrm{a}$ & 81 & 4.06 & $\mathrm{a}$ & 100 \\
\hline & A & 5.85 & $\mathrm{~b}$ & 62 & 1.26 & $\mathrm{~b}$ & 69 & 6.42 & $\mathrm{a}$ & 100 & 3.56 & $\mathrm{a}$ & 100 \\
\hline & $\mathrm{VC}$ & 15.84 & $\mathrm{a}$ & 100 & 8.53 & $\mathrm{a}$ & 89 & 1.76 & $\mathrm{a}$ & 90 & 3.44 & $\mathrm{a}$ & 90 \\
\hline \multirow[t]{4}{*}{3 rd year } & $\mathrm{VF}$ & 3.41 & $\mathrm{a}$ & 96 & 2.1 & $\mathrm{~b}$ & 28 & 1.87 & $\mathrm{a}$ & 80 & 5.27 & $\mathrm{a}$ & 100 \\
\hline & $\mathrm{C}$ & 2.16 & $\mathrm{~b}$ & 84 & 1.8 & $\mathrm{~b}$ & 44 & 2.08 & $\mathrm{a}$ & 88 & 8.27 & $\mathrm{a}$ & 100 \\
\hline & A & 2.08 & $\mathrm{~b}$ & 76 & 1.9 & $\mathrm{~b}$ & 44 & wd & & & 8.02 & $\mathrm{a}$ & 92 \\
\hline & $\mathrm{VC}$ & 2.28 & $\mathrm{~b}$ & 88 & 5.02 & $\mathrm{a}$ & 68 & 1.33 & $\mathrm{a}$ & 40 & 5.74 & $\mathrm{a}$ & 88 \\
\hline \multirow[t]{4}{*}{ 4th year } & $\mathrm{VF}$ & 1.2 & $\mathrm{a}$ & 48 & 1.94 & $\mathrm{~b}$ & 52 & 1.02 & $\mathrm{a}$ & 4 & 1.04 & $\mathrm{c}$ & 15 \\
\hline & $\mathrm{C}$ & 1.04 & $\mathrm{a}$ & 15 & 2.27 & $\mathrm{a}$ & 85 & 1.15 & $\mathrm{a}$ & 11 & 2.08 & $\mathrm{a}$ & 74 \\
\hline & A & 1.17 & $\mathrm{a}$ & 37 & 2.16 & $a b$ & 15 & 1.53 & $\mathrm{a}$ & 41 & 1.77 & $a b$ & 67 \\
\hline & $\mathrm{VC}$ & 1.14 & $\mathrm{a}$ & 26 & 1.89 & $\mathrm{~b}$ & 52 & 1.36 & $\mathrm{a}$ & 74 & 1.43 & $\mathrm{bc}$ & 15 \\
\hline
\end{tabular}

bulbs, which is consistent with data from other studies that evaluated garlic crops after 5 and 7 crop cycles (Conci et al. 2003; Melo Filho et al. 2006).

In a previous study, isolates of GarV-A and GarV-C were multiplied separately in anti-aphid cages to determine the effect of each virus on crop yield. Comparative tests were performed over 2 years and showed that the GarV-A isolate strongly affected crop yield by reducing bulb weight $14-32 \%$ (Cafrune et al. 2006). In contrast, the GarV-C isolate in the same study caused only mild damage to crop yield, if any, depending on the cultivar and the assays performed. Based on these data from Cafrune et al. (2006), GarV-A appears to be a more aggressive species than GarV-C. In the present study, garlic plants were infected with GarV-A and GarV-C isolates individually, in addition to infection with other naturally-occurring viruses. Both treatments were exposed to the same environmental conditions over 4 years. The effect on bulb weight of the two treatments differed from plants where only the individual isolates were present. The A and $\mathrm{C}$ treatments were also found to be re-infected in the field, thus losing their single virus status.

During the first growth cycle, mild damage in the $\mathrm{C}$ treatment was observed. A greater reduction in bulb weight for treatment $\mathrm{A}$ than treatment $\mathrm{C}$ also occurred, although neither group had bulb weights as low as the VC treatment. These differences became smaller as the number of crop cycles increased. Overall, these results were consistent with previous studies (Cafrune et al. 2006). In the second cycle, despite lower crop yields than in previous years, differences between VF and $\mathrm{C}$ treatments, with $\mathrm{A}$ and $\mathrm{VC}$ treatments, were observed. In the third growth cycle, the $\mathrm{C}$ treatment was not statistically different from the A treatment, and in the fourth cycle, both A and $\mathrm{C}$ treatments behaved similarly to the VC treatment. Plants originating from virus-free cloves continued to produce higher yields than the other plants, despite being infected with naturally-occurring viruses during propagation similar to all the other plant treatments.

In studies of sugar beets by Wintermantel and Kaffka (2006), low virus concentrations directly correlated with lower disease ratings and higher plant weight, and high virus concentrations correlated with higher disease ratings and lower weight. Similar results were observed for VC treated plants, with OYDV in the first and second years, and LYSV in the second and third years. Nevertheless, the effect of RC on bulb weight was not consistent; it was not found in other years or with other viruses. Moreover, the RC of OYDV was higher in the third year for VF treatment, which also showed the best yield. While RC increases 
would be expected in successive years, with the initial concentration exhibiting the lowest values in the first crop cycle and the highest values being detected at the end of the assay, this was not the case in this study.

The species of virus that infects a plant is another factor in bulb weight, with some virus species being more aggressive than others. OYDV in particular has been shown to significantly damage garlic yield (Canavelli et al. 1998; Conci 1997; Lot et al. 1998). However, in this work, OYDV infected VF treated plants in the first and second crop cycles and yet there was no correlation with changes in yield.

The greater degree of infection exhibited by VC treatments might be attributed to the span of the infection time allowed, since the VF plants had a similar percentage of infected plants to VC treatment, but the yield for the VF treatment was greater and the rate of decrease in bulb weight was slow. Based on these results, it appears that plants originating from cloves infected by viral isolates suffer greater yield losses than plants originating from virus-free cloves when both are subjected to infection by naturallyoccurring viruses. Therefore, we hypothesize that plants that experience longer times of infection are more susceptible to the synergistic interactions between the combinations of viruses that establish within the same plant. Probably the yield loss depends of the type of virus, the different virus combinations, virus concentration, and the time from the start of infection. Further study is needed to more clearly evaluate the contributions of these factors to crop yields for garlic as well as other plant species.

In several countries, certified seed programs only require the elimination of OYDV from the virus complex. Thus, the propagation material that is marketed may not be completely virus-free and may actually contain several other viruses. The propagation of these hidden viruses has the potential to increase re-infection rates and yield losses. In the present study, we found that 4 years after the collection of bulbs that contained at least one virus at the time of initial planting, and exposure to natural conditions, the bulbs had the same low yield values as a chronicallyinfected crop. Even when the initial infection was produced by an Allexivirus, independent of the species, crop yield decreased faster than for VF plants. Thus, the use of virus-free propagation material is recommended, independently of the damage each virus produces individually on garlic.
Since re-infection from neighboring fields can occur rapidly, it is essential that commercial crops be completely separated from propagating crops in order to avoid contamination.

\section{References}

Barg, E., Lesemann, D. E., Vetten, H. J., \& Green, S. K. (1994). Identification, partial characterization and distribution of viruses infecting Allium crops in South and Southeast Asia. Acta Horticulturae, 358, 251-258.

Bhojwani, S. S., Cohen, D., \& Fry, P. F. (1982). Production of virus free garlic and field performance of micropropagate plants. Scientia Horticulturae, 18, 39-43.

Cafrune, E. E., \& Conci, V. C. (2002). Aislamiento de Garlic virus $\mathrm{C}$. Actas de las XI Jornadas Fitosanitarias Argentinas (Abstract) Facultad de Agronomía y Veterinaria, Universidad Nacional de Río Cuarto, Córdoba, Argentina.

Cafrune, E. E., Giolitti, F., \& Conci, V. C. (2005). Purificación de Garlic virus C y producción de antisuero. XII Congreso Latinoamericano de Fitopatología y III Taller de la Asociación Argentina de Fitopatologos:583 Carlos Paz, Córdoba, del 19 al 22 de abril. (Abstract): 583.

Cafrune, E. E., Perotto, M. C., \& Conci, V. C. (2006). Effect of two Allexivirus isolates on garlic yield. Plant Disease, 90, 898-904.

Canavelli, A., Nome, S. F., \& Conci, V. C. (1998). Efecto de distintos virus en la producción de ajo (Allium sativum) Rosado Paraguayo. Fitopatología Brasilera, 23, 354-358.

Carvalho, M. G. (1981). Viroses do alho. Fitopatología Brasileira, 6(2), 299-300.

Carvalho, M. G., Shepherd, R. R., \& Hall, D. H. (1981). Virus em clone de alho sem sintomas e liberto do Garlic yellow stripe virus. Fitopatología Brasileira, 6(3), 236.

Clark, M. F. \& Adams, A. N. (1977). Characteristics of the microplate method of enzyme linked immunosorbent assay (ELISA) for the detection of plant viruses. Journal of General Virology, 34, 475-482.

Conci, V. C. (1997). Virus y Fitoplasmas de ajo. In J. L. Burba (Ed.), 50 temas sobre producción de ajo (pp. 267-293). Mendoza: EEA-INTA La Consulta.

Conci, V. C. \& Nome, S. F. (1991). Virus free garlic (Allium sativum L.) plants obtained by thermotherapy and meristem tip culture. Journal of Phytopathology, 132, 186-192.

Conci, V. C., Helguera, M., \& Nome, S. F. (1999). Serological and biological comparison of onion yellow dwarf virus from onion and garlic in Argentina. Fitopatología Brasilera, 24, 73-75.

Conci, V. C., Lunello, P., Buraschi, D., Italia, R. R., \& Nome, S. F. (2002). Variations of Leek yellow stripe virus concentration in garlic and incidence in Argentina. Plant Disease, 86, 1085-1088.

Conci, V. C., Canavelli, A., Lunello, P., Rienzo, J. D., Nome, S. F., Zumelzu, G., et al. (2003). Yield losses associated with virus-infected garlic plants during five successive years. Plant Disease, 87, 1411-1415.

Conci, V. C., Cafrune, E. E., Lunello, P., Nome, S., \& Perotto, C. (2004). Producción de planas de ajo libres de virus. In 
V. Echenique, C. Rubinstein \& L. Mroginski (Eds.), Biotecnología y Mejoramiento Vegetal (pp. 313-316). Buenos Aires: INTA.

Chen, J., Zheng, H. Y., Antoniw, J. F., Adams, M. J., Chen, J. P., \& Lin, L. (2004). Detection and classification of Allexiviruses from garlic in China. Archives of Virology, 149, 435-445.

Helguera, M., Bravo-Almonacid, F., Kobayashi, K., Rabinowicz, P. D., Conci, V. C., \& Mentaberry, A. (1997a). Immunological detection of a GarV-type virus in Argentine garlic cultivars. Plant Disease, 81, 1005-1010.

Helguera, M., Lunello, P., Nome, C., \& Conci, V. C. (1997b). Advances in the purification of filamentous viruses from garlic and in antisera production. Acta Horticulturae, 433, $623-630$.

InfoStat (2004). InfoStat, version 2004. Grupo InfoStat, Facultad de Ciencias Agropecuarias, Universidad Nacional de Córdoba, Argentina. Primera Edición

Lot, H., Chovelon, V., Souche, S., \& Delecolle, B. (1998). Effects of onion yellow dwarf and leek yellow stripe viruses on symptomatology and yield loss of three French garlic cultivars. Plant Disease, 82, 1381-1385.

Luciani, G. F., Cafrune, E. E., Curvetto, N. R., \& Conci, V. C. (1998). Obtención de plantas de ajo colorado (Allium sativum L.) libres de virus. Fitopatología, 33, 165-169.

Lunello, P., Helguera, M., Nome, S. F., \& Conci, V. C. (2002). An Argentinean isolate of Leek yellow stripe virus from leek can be transmitted to garlic. Journal of Plant Pathology, 84, 11-17.

Lunello, P., Di Rienzo, J., \& Conci, V. C. (2007). Yield loss in garlic caused by Leek yellow stripe virus Argentinean isolate. Plant Disease, 91, 153-158.

Melo Filho, P., Resende, R. O., Torres Cordeiro, C. M., Buso, J. A., Torres, A. C., \& Dusi, A. N. (2006). Viral reinfection affecting bulb production in garlic after seven year of cultivation under field conditions. European Journal of Plant Pathology, 116, 95-101.

Milne, R. G. \& Luisoni, E. (1977). Rapid immune electron microscopy of virus preparations. In K. Maramorosch \&
H. Koprowsk (Eds.), Meth in Vir (pp. 265-281). New York: Academic.

Nieto, A. M., Conci, V. C., \& Conci, L. R. (2004). Nucleotide sequence of the 3' region of a Carlavirus from Argentinean garlic mosaic. 4th International ISHS Symposium on Edible Alliaceae (ISEA). April 21-26, Beijing, China. Abstracts: 103

Perotto, M. C., Conci, V. C., Cafrune, E. E., Alochis, P., \& Bracamonte, R. (2003). Differences in the response of garlic cultivars to the eradication of five viruses. Phyton: $233-40$

Quiroga, M. P., Perotto, M. C., Cafrune, E. E., Torrico, A. K., Quevedo, V., \& Conci, V. C. (2005). Evaluación de daño producido por un aislamiento viral relacionado serológicamente con el GarV-D. Actas del IX Cuso/Taller sobre Producción Comercialización e Industrialización de ajo:133-4 Del 29 de junio al 2 de julio. Mendoza, Argentina. Ediciones INTA: 133-134

Tsuneyoshi, T. \& Sumi, S. (1996). Differentiation among garlic viruses in mixed infections based on RT-PCR procedures and direct tissue blotting immunoassays. The American Phytopathological Society, 86, 253-259.

Tsuneyoshi, T., Matsumi, K. T., Deng, T. C., Sako, I., \& Sumi, S. (1998). Differentiation of Allium carlaviruses isolated from different parts of the world based on the viral coat protein sequence. Archives of Virology, 143, 1093-1107.

Van Dijk, P., Verbeek, M., \& Bos, L. (1991). Mite-borne viruses from cultivated Allium species, and their classification into two new rymoviruses in the family Potyviridae. Netherlands Journal of Plant Pathology, 97, 381-399.

Van Dijk, P. (1993). Carlavirus isolates from cultivated Allium species represent three viruses. Netherland Journal of Plant Pathology, 99, 233-257.

Walkey, D. G. A. \& Antill, D. N. (1989). Agronomic evaluation of virus-free and virus-infected garlic (Allium sativum L.). Journal of Horticultural science, 64(1), 53-60.

Wintermantel, W. M. \& Kaffka, S. R. (2006). Sugar beet performance with curly top is related to virus accumulation and age at infection. Plant Disease, 90, 657-662. 